\title{
The role of the International Society of Citriculture on the world citrus industry
}

\author{
Dirceu Mattos-Jr. ${ }^{1} \&$ Eduardo Fermino Carlos $^{2}$
}

\begin{abstract}
SUMMARY
The International Society of Citriculture (ISC) is a permanent non-profit organization created in 1969 by citrus-oriented scientists and other interested professionals. The objective of the ISC is to strengthen internationally science and technology for the benefit of the worldwide citrus industry. The development of technology and expertise within the citrus production chain has supported the increase in production and the industry's expansion, gaining social and economic importance. These new demands have brought new challenges that will not be solved under the assumption of isolated and static systems. Therefore, the ISC has fostered the coordination of the world production chain in the search for academic and technological issues that lead to efficiency of production and consumption of citrus and related products by organizing the international citrus congress and other meetings. Based on reports available for 13 congresses organized by the ISC, renewed actions are required by ISC leadership to keep the highest levels of science and public concern for the betterment of citrus industries throughout the world.
\end{abstract}

Index terms: citrus, knowledge, development, congresses, membership, sustainability.

\section{O papel da Sociedade Internacional de Citricultura na indústria citrícola mundial}

\section{RESUMO}

A Sociedade Internacional de Citricultura (ISC) é uma organização permanente sem fins lucrativos criada em 1970 por cientistas na citricultura e outros profissionais interessados. O objetivo do ISC é fortalecer internacionalmente a ciência e a tecnologia para o benefício da indústria mundial de citros. O desenvolvimento de tecnologia e expertise dentro da cadeia produtiva dos citros tem apoiado o aumento da produção e a expansão da indústria, ganhando importância social e econômica. Essas novas demandas trouxeram novos desafios que não serão resolvidos sob a hipótese de sistemas isolados e estáticos. Portanto, o ISC tem promovido a coordenação da cadeia produtiva mundial na busca de questões acadêmicas e tecnológicas que levem à eficiência da produção e do consumo de produtos cítricos e afins, organizando o congresso internacional de citros e outros encontros. Com base em relatórios disponíveis de 13 congressos organizados pela ISC, novas ações são exigidas pela liderança do ISC para manter os mais altos níveis de ciência e interesse público para a melhoria indústria cítrica em todo o mundo.

Termos de indexação: citros, conhecimento, desenvolvimento, congressos, sócios, sustentabilidade.

\footnotetext{
${ }^{1}$ Centro de Citricultura Sylvio Moreira, Instituto Agronômico - IAC, Cordeirópolis, SP, Brasil

${ }^{2}$ Laboratório de Biotecnologia - LBI, Instituto Agronômico do Paraná - IAPAR, Londrina, PR, Brasil

Corresponding author: Dirceu Mattos-Jr., Centro de Citricultura Sylvio Moreira, Instituto Agronômico - IAC, Rod. Anhanguera, km 158, CP 04, CEP 13490-970, Cordeirópolis, SP, Brasil. E-mail: ddm@ccsm.br
} 


\section{THE GLOBAL CITRUS INDUSTRY}

Citrus trees produce oranges, mandarins, lemons, limes, grapefruits and citrons, which are consumed as fresh or processed as juice. Because of their great nutritious value, as a source of mineral nutrients, vitamins, fiber and other probiotic components, those are consumed worldwide as a major ingredient of the human diet. Furthermore, linked to important and well developed industrial and commercialization chains in the world, the citrus have been grown throughout tropical and sub-tropical regions from the northern to the southern Americas, in Asia and Australia as well in the Mediterranean regions and in Africa, mostly between latitude $40^{\circ} \mathrm{N}$ and $40^{\circ} \mathrm{S}$, in an area of approximately 8 million ha distributed in approximately 150 countries in the world.

Therefore, the citrus industry is present as a global and important economic activity that involves production on farms, processing of fruits at industrial plants and packinghouses, logistics of distribution and marketing of various citrus products that surpasses monetary figures of other fruit groups such as apples, bananas, grapes, pears or pineapples. In summary, the global citrus industry represents a multi-billion-dollar activity.

Notwithstanding this importance, meeting the citrus industry demands for high quality fruits and socioeconomic sustainability requires constant adaptation and innovation in several areas imposing heavily dedication of growers, processors, academia and others to a central idea supported by knowledge "from farm to fork" or better stated in the citrus business "from farm to glass" or even better, "from farm to people's health".

\section{THE INTERNATIONAL SOCIETY OF CITRICULTURE}

The International Society of Citriculture (ISC) has long supported the global citrus industry by connecting people, orienting work and transferring knowledge to all interested in this important activities in world agriculture. Conceived in 1968, the ISC was formed in 1970 and officially incorporated in 1976 by citrus-oriented scientists and other interested professionals, with the objective to strengthen internationally the development of science and technology for the benefit of the worldwide citrus industry.

Therefore, the ISC has developed the highest levels in leadership, publications, education and meetings achieved through collaborative interactions with the science community and public at large. Such actions significantly contribute to escalate research work, education and knowledge with respect to citrus genetics and genomics of scion and rootstocks, environmental physiology, plant growth and production, fruit quality, pests and diseases, microbiome, horticultural and health management, harvesting, handling, precision agriculture, processing, and policy and economics, also including public and consumers' perceptions.

Most of these above are achieved with the organization of events and conferences every four years in different citrus producing countries throughout the world in the format of the International Citrus Congress (ICC).

\section{THE INTERNATIONAL CITRUS CONGRESS}

Backing to the history of the ISC, it was during the activities to celebrate the $100^{\text {th }}$ anniversary of the University of California (1967-1968), a number of high quality citrus symposia was organized with the leadership of Dr. H.D. Chapman, when a first international citrus symposium was conducted as a major event on the university campus (Chapman, 1969). From that, other international citrus meetings were held worldwide as the International Citrus Congress (ICC), starting in 1973 (Table 1).

The ICC connects keynote speakers who address important topics for the citrus community, organizes parallel plenary sections aiming to cover the state of the art of every scientific field, as well up to date workshops to debate hot topics and industry perspectives. Additionally, the ICC fosters pre- and post-citrus tours in partnership with citrus organizations and consultants, which allow in-depth visits to different citrus production systems and local characteristics in every country. Parallel events and exhibitions also became an important part of the ICC program.

To emphasize this point, one sees the word of Dr. Peter Cary when expressed that he could not expect that the ICC could be held in Australia (1978), considering the local citrus industry was relative small in a global scale. However, what stood out was that the Australians had made a number of significant contributions to the world's scientific literature on all aspects of citrus production at that time (Cary, 1978). Furthermore, continuous contributions have been made throughout the period to the ISC Brazil meeting in 2016, one of the largest citrus industry in the world, conveying the work and expertise of more than 1.000 attendees from 35 countries (Mattos-Jr. et al., 2016). 
Table 1. The International Citrus Congresses around the world and correspondent number of delegates, abstracts presented and ISC members

\begin{tabular}{ccccccc}
\hline$\#$ & Year & Country & City & Delegates & Abstracts & ISC Members \\
\hline-- & 1968 & USA* & Riverside & 754 & 235 & - \\
1 & 1973 & Spain & Murcia/Valencia & 700 & 226 & 670 \\
2 & 1977 & USA & Orlando & 875 & 290 & $?$ \\
3 & 1978 & Australia & Sydney & 341 & 102 & 645 \\
4 & 1981 & Japan & Tokyo & 350 & 341 & 525 \\
5 & 1984 & Brazil & Sao Paulo & 424 & 285 & 512 \\
6 & 1988 & Israel & Tel-Aviv & 584 & 229 & 421 \\
7 & 1992 & Italy & Acireale & 886 & 469 & 501 \\
8 & 1996 & South Africa & Sun City & 545 & 299 & 567 \\
9 & 2000 & USA & Orlando & 1.015 & 508 & 526 \\
10 & 2004 & Morocco & Agadir & 890 & 366 & 280 \\
11 & 2008 & China & Wuhan & +1000 & 590 & 236 \\
12 & 2012 & Spain & Valencia & 1.212 & 760 & 225 \\
13 & 2016 & Brazil & Foz do Iguaçu & 1.009 & 452 & 177 \\
\hline
\end{tabular}

*International Citrus Symposium; ? = no data available. Siurce: adaptaed from Albrigo \& Coggins (2008).

Therefore, great knowledge has been streamed with attendance of people from research institutions, universities and extension services, consultants, growers and exhibitors, during the ICCs, representing the whole citrus industry, which outcome has been translated into increased sustainability based on efficiency of production and quality of citrus.

\section{A CHALLENGING FUTURE FOR THE INTERNATIONAL SOCIETY OF CITRICULTURE}

The role of the ISC as the largest network of experts representing all citrus-producing countries of the world is outstanding for education, research, development and innovation for the citrus industry.

This has been evident with the attendance at the ICC of more than 1.000 delegates after 2000 (Florida) compared to half of this average in the preceding congresses ${ }^{1}$ (Table 1). Furthermore, with the increased number of abstracts presented. Comparing the same period, after 2000 (Florida), an average of 535 were presented, an average significant higher than that of approximately 275 abstracts observed in the preceding congresses.

\footnotetext{
${ }^{1}$ Except data for 1968 (International Citrus Symposium).
}

Interestingly, the number of abstracts presented per delegate was about 0.5 in most congresses, except for Spain (1973), Australia (1978) and Israel (1988), when less than 0.3 abstract per delegate was presented (Table 1).

Another aspect on congress statistics, which deserves attention, concerns the number of ISC members, which has been decreasing over time. The highest number of members was observed in 1973 (670 members), just after the ISC foundation, while the smallest number in this series ( 180 members) was observed in the last edition of the ICC in 2016 (Table 1).

This later is probably a reflection of ISC's focus on a single crop of interest, while other scientific societies have a broader scope, easily aggregating a greater number of members. Also, ISC membership benefits are likely limited compared to other scientific societies, despite the four-year individual fee is quite low. Other facts, such as more proactive actions for the maintenance and increase of the number of members, carried out by the ISC executive committee are necessary.

These brief comments are contrary to the fact that attendance to the ICC has increased in recent years, as well as the effort of delegates to present more research results also, revealed by the ratio of abstract presented per delegate (Table 1). This suggests that members want more interaction.

Based on the above, the ISC Executive Board conducted a discussion on priority actions that should be implemented, within which, identifying the interests of 


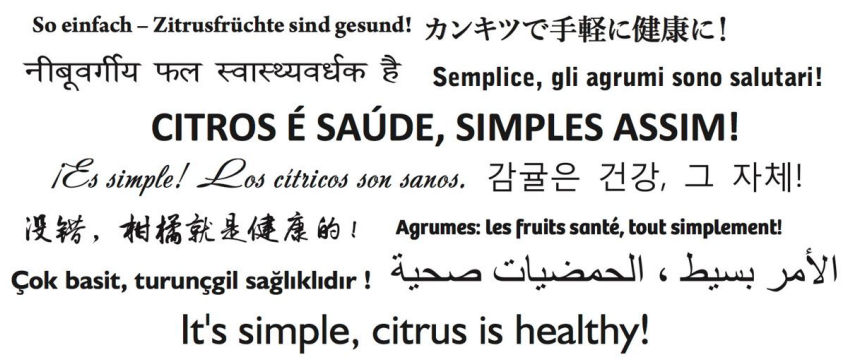

Figure 1. Positive message presented during the $13^{\text {th }}$ International Citrus Congress, in Brazil, in Arabic, Chinese, English, French, German, Hindu, Italian, Japanese, Korean, Portuguese, Spanish and Turkish languages.

current ISC members, motivating new potential members to join the ISC, extending ISC partnerships with other organizations, such as the International Organization of Citrus Virologists (IOCV) and the International Society of Citrus Nurserymen (ISCN), and the International Organization Society for Horticultural Science (ISHS), which relationship with ISC happened in the past, and discussing potential programs and deciding novel activities on its plan of work were included in the discussion.

Other actions as maintenance of ISC's webpage to keep it up to date, fostering photo contests related to "Citrus Trees and Orchards" themes, extending membership system/benefits, proceedings access and implementing young scientist awards were also discussed as attractive to the citrus community.

\section{WHAT NEXT?}

The ISC will need renewed actions to keep its highest levels in leadership with science and public at large building closer ties between related citrus communities, continuing to stream applied knowledge and connecting people to increase impact of research through the marketplace. Furthermore, engaging on promotion of incisive messages such as the health quality of citrus fruits all over the world (Figure 1).

\section{ACKNOWLEDGEMENTS}

The authors thank the São Paulo Research Foundation (Fapesp) grant \# 2016/01791-0, Conselho Nacional de Desenvolvimento Científico e Tecnológico (CNPq), Coordenação de Aperfeiçoamento de Pessoal de Nível Superior (Capes), Fundação Araucária, Fundação Agrisus and sponsors of the International Citrus Congress 2016. Also, thank Dr. Gene Albrigo for critical comments and helpful suggestions on this paper, as well Dr. Carol Lovatt and Yair Erner for providing Congresses numbers.

\section{REFERENCES}

Albrigo, L. G., \& Coggins, C. (2008). The International Society of Citriculture 1968 to 2008: the first 40 years. In Proceedings of the 1st International Citrus Symposium (p. 14-15). Riverside: University of California.

Cary, P. (1978). Welcome. . In Proceedings of the International Citrus Congress (p. 5-6). Sydney: International Society of Citriculture.

Chapman, H. (1969). Origin and organization of the first international citrus symposium. In Proceedings of the 1st International Citrus Symposium (p. 15-36). Riverside: University of California.

Mattos-Jr, D., Carlos, E. F., Novelli, V. M., Azevedo, F. A., Coletta Filho, H. D., \& Zaccheo, P. V. C. (2016). Sustainable citriculture: the role of applied knowledge. In Proceedings of the 13th International Citrus Congress (241 pp.). Londrina: ISC, IAC, IAPAR.

Received: November 11, 2017 Accepted: October 21, 2018 
